\title{
Tantangan Belajar Bahasa Inggris di Sekolah Pedesaan
}

\section{Challenges of Learning English in Rural School}

\author{
Hariya Harlina* \& Fazri Nur Yusuf \\ Universitas Pendidikan Indonesia, Bandung, Jawa Barat, Indonesia \\ hariyaharlina@gmail.com*
}

Naskah diterima tanggal 11/09/2020, direvisi akhir tanggal 23/12/2020, disetujui tanggal 31/12/2020

\begin{abstract}
Abstrak
Terdapat banyak kendala yang ditemukan pada pembelajaran bahasa Inggris di sekolah pedesaan. Kesulitan yang ditemui dalam pembelajaran bahasa Inggris di sekolah pedesaan berkaitan dengan kondisi siswa, lingkungan, dan juga kompetensi guru bahasa Inggris. Penelitian ini bertujuan untuk mengeksplor kendala yang muncul pada pembelajaran bahasa Inggris di sekolah pedesaan. Penelitian ini menggunakan desain metode kualitatif dengan dua guru bahasa Inggris sebagai responden. Hasil dari penelitian ini menunjukkan bahwa masih banyak kendala yang ditemui pada pembelajaran bahasa Inggris di sekolah pedesaan. Pembelajaran bahasa Inggris sulit karena beberapa sebab, diantaranya rendahnya minat siswa terhadap pelajaran bahasa Inggris, kurangnya support terhadap pembelajaran bahasa Inggris seperti support dari orang tua dan lingkungan sekitar, serta kualitas guru bahasa Inggris yang dinilai masih rendah.
\end{abstract}

Kata kunci: Tantangan Belajar Bahasa Inggris; Sekolah Pedesaan.

\begin{abstract}
There are many obstacles found in learning English in rural schools. The obstacles that encountered related to the student conditions, the learning environment, and the competence of English teachers. This study aims to explore the obstacles that occured in learning English in rural schools. This study used a qualitative research design with two English teachers as the respondents. The results showed that there are still many obstacles encountered by rural schools in learning English. Learning English is difficult because of several reasons, including the low interest of students in learning English, the lack of support for learning English such as support from parents and the environment, and the low quality of English teachers.
\end{abstract}

Keywords: Challenges in Learning English, Rural School. 


\section{PENDAHULUAN}

Bahasa Inggris merupakan salah satu bahasa terpenting di dunia saat ini (Crystal, 1997). Bahasa inggris sangat dibutuhkan hampir dalam semua aspek kehidupan seperti dunia pendidikan, dunia kerja, bisnis, dan lain sebagainya. Dengan menguasai bahasa Inggris seseorang dapat dikatakan berpeluang besar dalam berbagai kesempatan mendapat pekerjaan. Sehingga hal tersebut membuat semua negara mendorong warganya untuk belajar bahasa Inggris, tidak terkecuali Indonesia. Namun, posisinya sebagai bahasa asing di Indonesia membuat pengajaran bahasa Inggris memiliki tantangan tersendiri (Akbari, 2015). Bahasa Inggris telah diajarkan di negara ini sejak lama, mulai dari tingkat sekolah menengah hingga tingkat universitas, namun hal ini tidak menjamin siswa tidak mengalami kesulitan dalam belajar bahasa Inggris.

Pengajaran bahasa Inggris menjadi semakin sulit bagi siswa terutama ketika pembelajaran bahasa Inggris dikaitkan dengan konteks sekolah pedesaan. Hal tersebut sangat erat kaitannya dengan sumber daya dan lingkungan belajar yang tidak memadai. Sekolah pedesaan tidak memiliki banyak kesempatan untuk mengetahui bahasa Inggris seperti halnya sekolah perkotaan. Akses untuk mendapat informasi tentang bahasa Inggris sangat terbatas. Sehingga siswa dalam kesehariannya tidak mengenal bahasa Inggris dengan baik, yang kemudian hal tersebut berakibat pada kurangnya minat mereka dalam belajar bahasa Inggris.

Penelitian ini bertujuan untuk mengeksplor tantangan yang muncul pada pembelajaran bahasa Inggris di sekolah pedesaan. Sekolah pedesaan identik dengan fasilitas yang tidak memadai dalam berbagai aspek. Keberadaan buku-buku sebagai sumber belajar sering tidak cukup, ruang kelas yang tidak memadai, dan tidak tersedianya layanan internet yang pada saat ini telah menjadi hal umum dan biasa digunakan untuk mengakses sumber belajar lainnya. Ketersediaan gedung sekolah yang layak juga menjadi kendala. Bahkan beberapa sekolah seringkali tidak bisa melakukan proses pembelajaran saat musim penghujan tiba.

Selain itu, kurikulum yang sering kali berubah-ubah membuat guru dan pihak sekolah pedesaan kewalahan untuk mengikuti aturan kurikulum baru. Seperti contoh penggunaan kurikulum 2013 saat ini menjadi tantangan besar bagi guru maupun siswa sekolah pedesaan. Isi kurikulum 2013 lebih menekankan pembelajaran saintifik dimana pendekatan ini fokus ke keaktifan siswa dalam belajar. Hal tersebut menjadi tantangan yang besar bagi siswa karena pembelajaran mereka siswa sekolah pedesaan biasanya (jika tidak selalu) berfokus kepada guru.

Selain menjadi tantangan bagi siswa, kurikulum 2013 juga menjadi tantangan bagi guru dimana gurupun diharapkan mampu menjadi lebih kreatif dan inovatif dalam mengembangkan rencana pembelajaran di kelas. Kesuksesan kurikulum ini dipandang berkesempatan lebih besar pada sekolah kota yang tentunya memiliki pendukung yang maksimal. Sementara untuk sekolah pedesaan yang memiliki segala macam polemik terkait fasilitas dan pendukung pendidikan, pelaksanaan kurikulum 2013 yang notabenenya merupakan kurikulum yang banyak menggunakan media teknologi dirasa akan sulit terealisasi dan akan menyulitkan guru maupun siswa sendiri (Nurfuadah, 2014).

Bagian ini akan memaparkan kondisi sekolah pedesaan dan kualitas guru bahasa Inggris di sekolah pedesaan.

\subsection{Kondisi Sekolah Pedesaan}

Tantangan yang paling besar yang dihadapi oleh Indonesia dalam sistem pendidikannya adalah letak geografis yang luas serta banyaknya daerah pedesaan. Kesenjangan letak geografis dari daerah yang satu ke daerah yang lain membuat pemerataan fasilitas pendidikan menjadi hal yang sulit terwujud (Luschei \& Zubaidah, 2012, yang dikutip dari Febriana et al., 2018). Sekolah pedesaan memiliki karakteristik jumlah siswa pada setiap kelas cenderung lebih sedikit dan lokasi sekolah yang jauh dari perkotaan (Mccracken et al., 1991). Menurut Rich \& Evans (2009), jumlah siswa di setiap kelas sekolah pedesaan biasanya tidak lebih dari 30 siswa. Daerah sekolah pedesaan juga sering 
menggunakan konsep sekolah yang berlokasi di daerah pertanian dimana daerah pertanian acapkali dikaitkan dengan masyarakat tingkat ekonomi menengah kebawah (Bonnano, 2014, seperti dikutip dalam Biddle \& Azano, 2016).

Selain itu, du Plessis menyebutkan beberapa ciri-ciri daerah pedesaan menurut UNESCO 2005, diantaranya: jarak pedesaan yang umumnya jauh dari pusat perkotaan; kondisi topografi yang tidak mendukung, seperti kondisi jalan, jembatan dan lain sebagainya; akses ke berbagai teknologi informasi sangat kurang; serta infrastruktur transportasi seperti bus, taksi; akses ke layanan dan fasilitas seperti listrik, air, sanitasi; kesehatan, pendidikan, dan status ekonomi masyarakat yang cenderung di bawah garis kemiskinan.

Sekolah yang menjadi objek penelitian ini terletak di daerah pedesaan dimana tidak banyak media atau sumber belajar yang mendukung dalam pembelajaran bahasa Inggris. Di samping itu, kondisi siswa di dua sekolah tersebut tidak terlalu memperhatikan pentingnya belajar bahasa Inggris, begitu juga dengan lingkungan keluarga dan masyarakat sekitar. Sudut pandang masyarakat terhadap sekolah perkotaan dan pedesaan berbeda. Sekolah yang berada di daerah pedesaan cenderung memiliki siswa lebih sedikit dan biaya sekolah rendah daripada sekolah perkotaan (Howley et al., 2009).

Terkait dengan masalah ini, banyak (jika tidak semua) keluarga ekonomi menengah ke bawah yang tinggal di daerah pedesaan menganggap bahwa pendidikan tidak dapat menjamin kesuksesan dalam hidup mereka. Selain itu, daerah pedesaan adalah tempat yang ditandai oleh berbagai faktor seperti keterbatasan sarana dan prasarana, rendahnya kesejahteraan masyarakat, dan juga kualitas pendidikan yang dianggap tidak memadai dan pendidikan yang sering diabaikan (du Plessis, 2014). Hal ini dapat dilihat dari banyaknya orang tua yang menganggap bahwa pendidikan tidak dapat menjamin kesejahteraan hidup mereka.

Selain itu para orang tua juga tidak menginginkan anaknya meninggalkan rumah. Kekhawatiran mereka dilatarbelakangi oleh alasan bahwa pada umumnya, anak-anak atau 327 pemuda yang meninggalkan komunitas pedesaan baik untuk belajar atau bekerja ke luar daerah tidak akan pernah kembali. Mereka akan menetap di daerah tertentu untuk mencari penghidupan yang lebih baik dari daerah asal mereka (Stricker, 2008, seperti dikutip dalam Howley et al., 2009). Pola pikir orang tua yang telah ditanamkan sejak awal tidak dapat diubah dengan mudah. Para orang tua sulit membiarkan anak mereka masuk sekolah maupun melanjutkan pendidikan ke jenjang yang lebih tinggi. Mereka lebih menyukai anak mereka bekerja daripada bersekolah (Febriana et al., 2018).

Kesulitan ekonomi juga menjadi salah satu kendala bagi masyarakat pedesaan dan membuat para orang tua untuk tidak menyekolahkan anak-anak mereka ke jenjang yang lebih tinggi. Bahkan, tidak sedikit dari masyarakat pedesaan yang tidak pernah mengenyam bangku sekolah sejak lahir, tidak juga bangku sekolah dasar. Sehingga orang tua yang buta huruf dan tidak bisa berhitung banyak ditemukan daerah pedesaan (du Plessis, 2014). Pelajar di daerah pedesaan tidak mendapat dukungan yang cukup dari orang tua mereka karena alasan-alasan tersebut. Kondisi ini bahkan menjadi lebih buruk karena pendapat dari masyarakat sekitar dan bahkan pihak pemerintah yang menganggap hal ini sebagai hal yang biasa terjadi di daerah pedesaan. Daripada membantu untuk meluruskan pola pikir masyarakat pedesaan tentang pendidikan, mereka lebih condong membiarkan hal tersebut sebagai suatu hal yang lumrah terjadi.

Selain itu, sumber daya pendukung pembelajaran seperti buku, media proyektor, dan lainnya tidak tersedia dengan cukup, sehingga fokus pembelajaran hanya pada penjelasan guru (DeYoung, 1991; Febriana et al., 2018). Faktor-faktor itu membuat masyarakat dari keluarga ekonomi menengah ke atas cenderung meremehkan sekolah di daerah pedesaan dan lebih suka memasukkan anak-anak mereka ke sekolah favorit yang sebagian besar memiliki biaya sekolah tinggi dan fasilitas sekolah yang memadai. Sudut pandang tersebut secara tidak langsung mempengaruhi pola pikir siswa sekolah pedesaan. Siswa sekolah pedesaan cenderung merasa rendah diri dan menganggap diri Jurnal Penelitian Pendidikan 
mereka tidak lebih baik daripada siswa di sekolah perkotaan (Hargreaves et al. 2009, dikutip dari Febriana et al., 2018).

\subsection{Kualitas Guru Bahasa Inggris}

Guru memiliki peran penting dalam mencapai tujuan pembelajaran di kelas. Guru sebagai pendidik haruslah seseorang yang memiliki profesionalisme tinggi dan kemampuan tinggi untuk membantu mendidik siswa. Guru harus mampu menjahit potongan tantangan sebagai jalan yang dapat dilalui agar siswa tidak terpuruk pada motivasi rendah dalam belajar. Guru adalah pendidik profesional dengan tugas utama mendidik, membimbing, mengajar, mengarahkan, melatih, menilai dan mengevaluasi siswa dalam pendidikan formal (Sadulloh, 2018).

Keterampilan guru yang berbeda dapat menghasilkan hasil belajar yang berbeda juga. Oleh karena itu, diharapkan guru bahasa Inggris dapat memiliki pengetahuan yang luas dalam membimbing siswa dalam mengembangkan kemampuan belajar bahasa Inggris. Mutu sekolah pedesaan lebih rendah dibanding sekolah di perkotaan dilihat dari ketersediaan guru yang berkompeten dan akses terhadap sumber belajar yang lebih mudah.

Beberapa penelitian menganggap bahwa guru di sekolah perkotaan memiliki lebih banyak akses dalam mengembangkan materi pelajaran, sedangkan guru sekolah pedesaan lebih sering kekurangan akses dalam mengembangkan materi pelajaran. Hal ini kemudian mendorong proses pembelajaran di kelas hanya berfokus kepada guru (Hargreaves et al. 2009, dikutip dari Febriana et al., 2018). Fokus pembelajaran yang hanya berada di tangan guru mengakibatkan siswa tidak memiliki kemauan dan kemampuan dalam belajar mandiri. Barley \& Beesley (2007, dikutip dari du Plessis, 2014) juga mengemukakan bahwa ketidakberhasilan pembelajaran bahasa Inggris di sekolahsekolah pedesaan dipengaruhi oleh kekurangan guru yang berkualitas dan sumber daya yang mendukung proses pembelajaran. Sekolah pedesaan mengalami kesulitan untuk merekrut guru yang berkualitas karena beberapa pertimbangan, termasuk akses Jurnal Penelitian Pendidikan terbatas ke sekolah, gaji yang lebih sedikit jika dibandingkan sekolah perkotaan, sumber daya dan fasilitas sekolah yang tidak mencukupi (du Plessis, 2014; Knoblauch \& Chase, 2015).

Biddle \& Azano (2016) juga mengidentifikasi perekrutan guru dan pelatihan guru sebagai topik umum yang sebagian besar muncul di sekolah pedesaan. Guru-guru sekolah pedesaan perlu memiliki pelatihan mengenai proses belajar-mengajar, seperti pengembangan metode dan strategi dalam pengajaran bahasa Inggris, pelatihan penggunaan media ajar, maupun pelatihan dalam membuat materi yang menarik minat siswa. (Shibley, 1917, seperti dikutip dalam Biddle \& Azano, 2016) menyatakan bahwa isolasionisme di pedesaan sering berdampak pada proses belajar-mengajar di sekolah. Oleh karena itu, guru di sekolah pedesaan membutuhkan lebih banyak pelatihan dan persiapan awal.

Seorang guru dikatakan berkualitas salah satunya dikarenakan guru memiliki kemampuan untuk merancang kegiatan belajar dalam suatu rencana pembelajaran, dimana rencana pembelajaran itu merupakan kelengkapan belajar yang diambil dari kurikulum pendidikan dan menjadi panduan utama proses pembelajaran. Seperti yang dikatakan Nunan (1999) bahwa kurikulum pendidikan merupakan elemen yang sangat penting pada proses pembelajaran dan guru sebagai pendidik memegang peranan penting dalam mengimplementasikannya di kelas. Richard (2001, seperti dikutip Nurfuadah, 2014) mengatakan kurikulum pendidikan terdiri dari seluruh kegiatan pembelajaran di kelas, dimulai dari bagaimana siswa belajar, bagaimana guru membantu siswa belajar, jenis materi pembelajaran, metode apa yang diterapkan guru, bagaimana guru menilai tugas siswa, serta mencakup fasilitas pembelajaran yang digunakan di dalam kelas.

Kegiatan belajar harus dimasukkan dalam perangkat rencana pembelajaran yang berisi tujuan pembelajaran, indikator, dan lain-lain, sebagai target yang diharapkan dari proses belajar-mengajar. Selain itu, untuk mengetahui apakah tujuan pembelajaran telah dicapai oleh siswa, proses penilaian (assessment) hasil siswa perlu dilakukan (Jabbarifar, 2009; Looney et al., 2018). Penilaian pembelajaran 
adalah bagian penting dari keseluruhan proses pembelajaran sehingga kegiatan penilaian harus dilakukan oleh guru selama proses pembelajaran.

Ada dua fungsi utama penilaian kelas, pertama adalah untuk menunjukkan apakah proses pembelajaran telah berhasil mencapai tujuan pembelajaran atau tidak, kedua adalah untuk menjelaskan harapan para guru tentang siswa (Biggs, 1999; Dunn et al., 2004, seperti dikutip di Jabbarifar, 2009). Dengan demikian, kemampuan untuk melakukan penilaian adalah kemampuan yang diperlukan untuk setiap staf pengajar. Jelaslah bahwa dalam semua referensi yang berkaitan dengan tugas belajar, selalu ditekankan pentingnya kemampuan guru untuk menilai dan kemampuan ini selalu menjadi salah satu indikator kualitas kompetensi guru.

Terlepas dari itu, seorang guru yang baik juga dapat dilihat dari beberapa hal diantara kepribadian guru, perilaku guru terhadap siswa di dalam dan di luar kelas, pemahaman guru tentang kebutuhan siswa, dan bahkan dari gaya berpakaian guru (Harmer, 2007). Sebagai tambahan, guru yang baik adalah orang yang mampu menginspirasi siswa, menghormati siswa, membuat suasana yang baik dalam mengajar, menyediakan beberapa media kreatif, memperhatikan kebutuhan siswa dan menghargai usaha yang dilakukan siswa saat proses belajar-mengajar berlangsung. Juga, guru yang baik adalah seseorang yang dapat mengoreksi atau mengkritik siswa tanpa menyinggung perasaan mereka (Harmer, 2007).

Meskipun masing-masing guru memiliki kepribadian yang beragam serta cara yang berbeda dalam berinteraksi dengan siswa, namun etika guru yang baik dapat lebih memberi kesan yang baik terhadap siswa sehingga hal tersebut secara tidak langsung bisa mempengaruhi kepercayaan diri siswa dalam mengajar.

\section{METODE PENELITIAN}

Penelitian ini menggunakan desain penelitian kualitatif. Desain penelitian ini digunakan untuk mengeksplorasi dan memahami makna individu atau kelompok yang terkait dengan masalah sosial (Creswell
\& Guetterman, 2018). Penelitian ini bertujuan untuk mengetahui tantangan dari pembelajaran bahasa Inggris yang ada di sekolah pedesaan. Pertanyaan yang muncul terkait dengan topik penelitian ini adalah (1) Apa saja tantangan belajar bahasa Inggris yang sering muncul di sekolah pedesaan?

Partisipan dalam penelitian ini adalah dua guru bahasa Inggris dari dua sekolah yang berbeda. Untuk mengumpulkan data, wawancara semi-struktur dan observasi kelas telah dilakukan. Wawancara semi-struktur bertujuan untuk mengetahui tantangan belajar bahasa Inggris dari perspektif guru bahasa Inggris. Wawancara semi-struktur digunakan untuk mendapat data yang lebih luas dan dalam.

Instrumen selanjutnya adalah observasi kelas, dimana observasi ini bertujuan untuk mengamati perilaku guru dan siswa saat proses pembelajaran berlangsung. Jenis observasi kelas yang digunakan adalah observasi nonpartisipan yang artinya peneliti hanya datang sebagai observer, tidak mengambil bagian dari aktifitas belajar di kelas.

Data yang diperoleh dianalisis dengan menggunakan empat langkah, yaitu: kode, konsep, kategori, dan teori (Mente et al., 2011). Data yang diperoleh dari dua instrumen kemudian dikodekan untuk menemukan data yang dibutuhkan untuk menjadi data yang dapat memberikan jawaban atas pertanyaan dalam penelitian, dikarenakan tidak semua data yang diperoleh sesuai dengan kebutuhan penelitian, terutama data yang diperoleh dari jenis pertanyaan terbuka.

Setelah melalui tahap pengkodean, data kemudian dikonseptualisasikan atau disatukan sesuai dengan kesamaan konten. Selanjutnya data dikategorikan sehingga akan menghasilkan teori, dan tahap terakhir adalah data dijelaskan secara lebih detail dan mendalam, sehingga akan membentuk teori penelitian.

\section{HASIL DAN PEMBAHASAN}

\subsection{Hasil}

Penelitian ini bertujuan untuk mengeksplore kesulitan dalam pembelajaran bahasa Inggris di sekolah pedesaan. Observasi kelas dan wawancara digunakan untuk Jurnal Penelitian Pendidikan 
mengambil data. Hasil data yang didapatkan dianalisis menggunakan empat metode yang dirancang oleh (Mente et al., 2011). Data yang didapat dari penelitian ini menunjukkan bahwa sekolah pedesaan mengalami kesulitan dalam pembelajaran bahasa Inggris di kelas. Kesulitan tersebut akan dibahas secara mendalam di bagian selanjutnya.

\subsection{Pembahasan}

Penelitian ini menemukan bahwa pembelajaran bahasa Inggris di sekolah pedesaan mempunyai kendala yang lebih besar jika dibandingkan dengan sekolah yang berada di perkotaan (Plessis, 2014; Ponmozhi \& Thenmozhi, 2017; Hargreaves et al. 2009, dikutip dari Febriana et al., 2018).

Hal tersebut dikarenakan berbagai faktor di antaranya minat siswa terhadap pelajaran bahasa Inggris terhitung rendah, kurangnya dukungan dari orang tua dan lingkungan, serta kompetensi guru bahasa Inggris yang terbilang rendah. Berikut adalah penjelasan lebih lanjut dari faktor yang menjadi kendala pembelajaran bahasa Inggris di sekolah pedesaan.

\section{A. Minat Siswa Terhadap Bahasa Inggris}

Bahasa Inggris saat ini dikenal luas oleh siswa di sekolah kota, namun lain halnya dengan sekolah yang ada di pedesaan (Ponmozhi \& Thenmozhi, 2017). Bahasa Inggris di lingkungan pedesaan tidak dikenal secara luas baik itu di dalam lingkungan sekolah maupun di luar sekolah (du Plessis, 2014). Siswa pedesaan tidak mengetahui pentingnya belajar bahasa Inggris selain sebagai salah satu mata pelajaran pada ujian nasional.

Kurangnya pengetahuan tentang bahasa Inggris sangat berpengaruh besar pada minat belajar yang tumbuh pada diri siswa. Selain itu, anggapan bahwa bahasa Inggris adalah pelajaran yang sulit membuat mereka tidak menaruh minat yang besar dalam belajar bahasa Inggris. Banyak dari mereka belajar bahasa Inggris tidak secara maksimal. Bahkan banyak dari siswa hanya bertujuan untuk menjawab ujian nasional saja. Selain itu, banyak siswa yang mengabaikan pelajaran bahasa Inggris dan menjadikannya pilihan kesekian dari pelajaran yang lain.

Holguín \& Morales (2016) juga menambahkan bahwa minat rendah dalam belajar dilihat dari tingkah laku siswa selama proses pembelajaran di kelas berlangsung, seperti siswa tidak menunjukkan antusias selama proses pembelajaran bahasa Inggris. Pada penelitian ini ditemukan bahwa sebagian besar siswa tidak memperhatikan penjelasan guru dengan baik. Mereka bahkan mengerjakan hal lain seperti membaca novel, menggambar, bercanda dengan teman lainnya.

Kemudian saat guru mencari perhatian dengan menanyakan materi yang disampaikan, sebagian besar siswa terdiam, sebagian lagi merespon dengan mengatakan 'yes/no' walaupun pertanyaan jauh berbeda dari jawaban 'yes/no'. Bahkan beberapa siswa tertawa mendengar jawaban mereka sendiri, yang menunjukkan bahwa mereka tidak benarbenar serius dalam belajar.

Hal tersebut mencerminkan siswa tidak paham dengan penjelasan maupun pertanyaan yang dilontarkan oleh guru. Selain itu, siswa sering kali meninggalkan kelas saat pelajaran berlangsung dan kembali ke kelas saat jam pelajaran usai. Hal tersebut sesuai dengan hasil wawancara yang dilakukan kepada dua guru di dua sekolah.

Guru pertama; "Siswa laki-laki suka keluar kelas dan tidak kembali sampai pelajaran habis. Saya tidak mungkin mencari mereka sedangkan waktu belajar hanya dua jam. Jadi saya serahkan kasus seperti ini ke guru BK. Saya laporkan mereka yang bertingkah dan tidak mau dibilangin. Hampir di setiap jam pelajaran saya selalu ada kasusnya. Dan kasus ini sering terulang, mereka tidak kapok."

Kendala lain yang ada di sekolah pedesaan terkait dengan siswa adalah siswa tidak ingin mengerjakan tugas yang diberikan oleh guru. Berbagai macam alasan mereka kemukakan agar guru tidak memberikan tugas kepada mereka, di antara alasan-alasan itu adalah siswa merasa tidak paham atas tugas yang diberikan guru sehingga mereka tidak akan mungkin bisa mengerjakannya. Hal tersebut seringkali terjadi yang membuat guru bahasa Inggris kewalahan.

Guru pertama: "Kalau dikasih tugas itu mereka kebanyakan ngeluh, ngeluh karena 
tidak bisa menjawab. Nantinya tugas sekolah itu terpaksa saya jadikan PR karena mereka tidak pernah menyelesaikan tugasnya dengan tepat waktu. Banyak sekali alasan mereka. Jadi mau tidak mau saya jadikan dijadikan PR. Besoknya, belum tentu juga mereka kerjakan. Alasan lupa bawa dan macammacam."

Kasus yang lain terjadi di sekolah kedua dimana siswa tidak pernah hadir pada kegiatan kursus tambahan yang diadakan di sekolah. Kursus yang diadakan oleh pihak sekolah dijadwalkan dua kali seminggu, yang bertujuan untuk memberi pelajaran tambahan serta memberi tambahan waktu untuk menyelesaikan materi di kelas yang belum tuntas. Namun hanya segelintir siswa yang hadir dalam kursus tersebut. Bahkan beberapa kali tidak ada siswa yang hadir sama sekali.

Sebagian besar siswa beralasan bahwa mereka mempunyai banyak kegiatan ekstra kulikuler yang dilakukan sepulang sekolah, sehingga mereka tidak bisa hadir dalam pelajaran tambahan di sore hari. Ditambah lagi, siswa tidak jujur dalam mengerjakan tugas. Ketika diberikan PR membuat sebuah teks, sebagian besar siswa biasanya mencari teks yang sudah tersedia di buku maupun di sumber lain, daripada membuat sendiri sesuai kemampuan mereka. Hal tersebut mereka akui sendiri pada gurunya tanpa rasa bersalah.

Guru kedua; "Kalau mereka benar-benar niat dan ingin belajar, tentu saja mereka akan memilih bahasa Inggris daripada kegiatan yang lain. Tapi buktinya hanya segelintir siswa yang datang saat kursus. Saya juga bilang, minimal datang sekali seminggu, tapi tidak ada yang mau. Banyak alasannya anakanak ini kalau disuruh belajar."

Guru kedua: "Berapa kali saya bilang bikin tugas sesuai kemampuanmu, tapi begitulah mereka. Ketika saya bandingkan tugas yang asli dengan yang hasil contekan, kelihatan jelas mana hasil mereka. Saat mereka ditanya, ya mereka ngaku. Mereka akan bilang, -yang penting jadi Bu GuruAduh, saya tidak tahu harus bagaimana. Cuma sedikit siswa yang sadar dan mau bikin tugas sendiri."
B. Pengaruh Lingkungan

Lingkungan dinilai sangat berpengaruh terhadap diri seseorang. Lingkungan berpengaruh membentuk mindset maupun motivasi seseorang untuk melakukan sesuatu, tidak terkecuali bagi siswa sekolah pedesaan dalam belajar bahasa Inggris.

Pada umumnya, motivasi didefinisikan sebagai cara untuk mempengaruhi seseorang atau banyak orang untuk melakukan sesuatu yang di dalamnya terdapat tujuan tertentu (Uno \& Lamatenggo, 2010). Lingkungan sekolah pedesaan yang tidak familiar dengan bahasa Inggris membuat siswa juga tidak menaruh minat besar terhadap pembelajaran bahasa Inggris.

Selain itu, lingkungan keluarga atau orang tua dan tempat tinggal juga sangat berperan dalam membantu meningkatkan kualitas belajar siswa. Namun, peran orang tua di lingkungan pedesaan dalam membantu siswa belajar bahasa Inggris dinilai sangat rendah (Holguín \& Morales, 2016).

Para orang tua tidak membantu siswa belajar dan juga tidak mengontrol siswa secara maksimal. Orang tua di daerah pedesaan tidak memberikan motivasi secara khusus untuk siswa dalam mengembangkan kemampuan belajar mereka terutama yang berkaitan dengan pembelajaran bahasa Inggris. Para orang tua lebih menekankan anak untuk bekerja daripada bersekolah. Hal tersebut terkait dengan kondisi perekonomian di lingkungan pedesaan yang biasanya berasal dari ekonomi kelas menengah ke bawah. Sehingga, walaupun anaknya bersekolah, mereka tidak mengontrol sejauh mana perkembangan anaknya dalam proses belajar di sekolah. Pernyataan tersebut didukung oleh data yang didapatkan dari wawancara dengan dua guru bahasa Inggris dari dua sekolah.

Di sekolah kedua, dimana siswa tinggal di asrama dalam lingkungan sekolah, guru menganggap minat siswa belajar bahasa Inggris lumayan besar. Akan tetapi minat yang besar itu tidak sejalan dengan usaha yang siswa lakukan dalam proses belajarnya.

Guru pertama: "Karena mereka tinggal di asrama, menurut saya lingkungannya mendukung. Jika ditanya apakah mereka minat dalam pelajaran bahasa Inggris, ya mereka akan jawab minat. Tapi kalau disuruh ngerjain Jurnal Penelitian Pendidikan 
soal latihan saja, mereka ngeluh semua. Mereka akan bilang bahasa Inggris itu sulit. Jadi kan minat ya sekedar minat, gak didukung dengan usaha mereka. Menurut saya ya gitu. Minat harus dibarengi usaha kan?"

Sebagai tambahan, di sekolah kedua, guru menyampaikan polemik yang dihadapi siswa terkait dengan kondisi ekonomi keluarga dan lingkungan sekitar tempat tinggal yang tidak mendukung siswa dalam menjalankan peran sebagai pelajar.

Guru kedua: "Anak-anak di sini sekolah sambil kerja. Pada saat jadwal mereka kerja, mereka tidak akan masuk sekolah. Dalam seminggu bisa dihitung sehari dua hari mereka bisa masuk sekolah, tiga hari tidak masuk ya alasannya karena kerja. Nanti kalau kami larang mereka kerja, mereka pasti akan jawab gak punya uang belanja. Jadi kami bisa apa?"

Guru kedua: "Lagipula di lingkungan tempat tinggal mereka, banyak teman sebaya mereka yang tidak bersekolah. Jadi mereka kadang ikut-ikutan tidak sekolah. Dan yang saya heran, orang tua tidak melarang. Dilepas begitu saja."

\section{Kompetensi Guru Bahasa Inggris}

Kompetensi guru dinilai dari kemampuan mereka dalam merancang dan melaksanakan pembelajaran di kelas dengan baik dan maksimal sehingga tujuan pembelajaran mampu dicapai secara maksimal juga. Dua guru bahasa Inggris dari dua sekolah ini memiliki cara yang berbeda dalam melaksanakan pembelajaran di kelas.

Guru bahasa Inggris di sekolah pertama menyampaikan materi sesuai dengan apa yang ada di buku paket. Penjelasan materi diuraikan dengan bahasa yang sederhana untuk membuat siswa cepat mengerti. Guru menyampaikan materi secara detail, seperti menjelaskan pengertian teks, struktur teks, ciri-ciri kebahasaan teks, tujuan serta menunjukkan contoh yang kemudian dibahas bersama.

Setelah selesai membahas contoh teks, guru meminta siswa membuat teks seperti yang sudah dibahas bersama sebagai tugas. Sebelumnya, guru meminta siswa bertanya terkait materi yang belum mereka pahami. Jurnal Penelitian Pendidikan
Pertanyaan yang muncul dari siswa bukan ketidakmengertian mereka tentang isi materi, akan tetapi siswa lebih banyak menanyakan arti kosa kata yang tidak dipahami dari contoh teks yang ada.

Hal tersebut dikarenakan siswa tidak memiliki kamus yang lengkap sebagai salah satu sumber belajar. Sekolah hanya menyediakan beberapa kamus yang dibagi dengan kelas lain yang juga mempunyai jadwal bahasa Inggris di hari yang sama. Ini menjadi salah satu bukti bahwa fasilitas sekolah sangat membantu terlaksananya proses pembelajaran di kelas. Jika fasilitas pembelajaran tidak memadai, maka proses pembelajaran bisa terhambat (Holguín \& Morales, 2016).

Guru kedua menggunakan metode yang berbeda. Guru bahasa Inggris di sekolah kedua meminta masing-masing siswa maju ke depan kelas untuk membaca satu paragraf dari teks yang ada di buku, dimana tujuannya adalah untuk melatih kemampuan membaca siswa. Guru bahasa Inggris menyatakan bahwa siswa masih kesulitan dalam membaca teks bahasa Inggris. Siswa masih membaca kosa kata bahasa Inggris sesuai dengan tulisannya dan dengan pengucapan yang tidak tepat.

Sebagai contoh pembacaan kata 'earth' dibaca 'heart'; 'noticeable' dibaca 'notaisable'; 'conclusion' dibaca sesuai tulisannya 'conclusion' dan lain sebagainya. Siswa juga belum lancar dalam mengucapkan angka dalam bahasa Inggris seperti pengucapan '2007, 2010, 2018' dan seterusnya. Siswa masih tidak mampu membedakan bilangan dasar maupun bilangan bertingkat serta pengucapannya. Setelah itu, guru meminta siswa menjawab soal yang berkaitan dengan teks yang sudah dibaca. Di sana, siswa merasa kesulitan dalam memahami tugas mereka karena guru belum menjelaskan materi secara detail.

Pada kasus ini, metode mengajar yang guru gunakan perlu dipertimbangkan agar siswa tidak kebingungan saat mengerjakan tugas. Seperti yang dikatakan Harmer (2007) bahwa perbedaan metode mengajar bisa jadi menghasilkan pemahaman siswa yang berbeda serta membuat pencapaian belajar berbeda pula. Kedua guru memberikan contoh teks yang diambil dari internet dengan topik yang cukup berat, dengan kosa kata yang tidak 
mudah dipahami siswa. Untuk meminimalisir kebingungan siswa, guru sebaiknya memberikan contoh teks dengan topik yang sederhana dan dengan kosa kata yang tidak terlalu sulit agar siswa bisa memahami teks dengan mudah.

Selain itu, seorang guru yang berkualitas adalah mereka yang mempunyai kemampuan untuk merancang rencana kegiatan belajar. Kegiatan belajar harus dimasukkan dalam rencana pembelajaran yang berisi tujuan pembelajaran sebagai target yang diharapkan dari proses belajar-mengajar. Untuk mengetahui apakah tujuan pembelajaran telah dicapai oleh siswa, proses penilaian hasil siswa perlu dilakukan (Jabbarifar, 2009; Looney et al., 2018).

Seluruh rangkaian ini tercakup dalam rencana pelaksanaan pembelajaran (RPP). Guru yang baik seharusnya mempunyai perangkat pembelajaran yang digunakan sebagai pedoman dalam belajar. Namun kenyataannya, penggunaan RPP tidak pernah berjalan sebagaimana mestinya. Apa yang tertulis di RPP tidak pernah sejalan dengan realita pembelajaran di sekolah desa. Kedua guru bahasa Inggris di dua sekolah tersebut mengaku tidak pernah menggunakan RPP saat mengajar.

Guru pertama dan kedua: "Tidak bisa. Pemakaian RPP tidak bisa berjalan di sini. Kondisi siswa di sini berbeda. Apalagi sama anak-anak ini. Mereka susah dibilangin. Memperhatikan penjelasan saja, saya harus teriak-teriak sampai serak, baru mereka mau sedikit memperhatikan. Jadi saya tidak pernah berpatokan dengan RPP."

\section{KESIMPULAN}

Pembelajaran di sekolah pedesaan tidak bisa dipandang sebelah mata. Terkait dengan kondisi lingkungan yang serba kekurangan, guru bahasa Inggris diharapkan memiliki kemampuan yang tepat untuk teknik pengajaran di daerah pedesaan, serta mempunyai cara untuk mengatasi kondisi siswa maupun kondisi fasilitas sekolah yang biasanya tidak memadai.

Namun pada kenyataannya, kompetensi guru bahasa Inggris di sekolah pedesaan dinilai lebih rendah daripada guru di sekolah perkotaan (Hargreaves et al. 2009, dikutip dari Febriana et al., 2018). Akses terhadap sumber belajar, fasilitas sekolah yang tidak memadai, serta gaji yang sedikit membuat sekolah di pedesaan sulit untuk merekrut guru yang berkompeten, sehingga proses pembelajaran di kelas hanya berfokus kepada guru (du Plessis, 2014; Knoblauch \& Chase, 2015).

Guru-guru di sekolah pedesaan juga tidak difasilitasi dengan pelatihan terhadap proses pembelajaran seperti pelatihan kurikulum terbaru, dimana seharusnya guru juga harus memperoleh pelatihan guna tercapainya tujuan pembelajaran sesuai kurikulum yang berlaku.

Pelatihan terhadap guru merupakan hal yang sangat penting dilakukan, karena merupakan salah satu cara untuk meningkatkan kompetensi guru dalam mengajar (Holguín \& Morales, 2016).

Selain itu tantangan yang seringkali muncul pada pembelajaran bahasa Inggris di sekolah pedesaan adalah kurangnya minat siswa terhadap pelajaran bahasa Inggris, kurangnya dukungan orang tua pada perkembangan belajar siswa, serta kurangnya jumlah guru yang berkompeten mengajar bahasa Inggris. 


\section{DAFTAR PUSTAKA}

Akbari, Z. (2015). Current Challenges in Teaching/Learning English for EFL Learners: The Case of Junior High School and High School. Procedia - Social and Behavioral Sciences, 199, 394-401. https://doi.org/10.1016/j.sbspro.2015.07.524

Biddle, C., \& Azano, A. P. (2016). Constructing and Reconstructing the "Rural School Problem." Review of Research in Education, 40(1), 298-325. https://doi.org/10.3102/0091732X16667700

Cooney, S., \& Bottoms, G. (2003). Middle Grades to High School: Mending a Weak Link. Research Brief. Southern Regional Education Board, 592 10th St. N.W., Atlanta, GA 30318. Tel: 404-875-9211; Web site: http://www.sreb.org. For full text: http://www.sreb.org/programs/hstw/publications/briefs/Middle_Grades_To_HS.pdf. www.sreb.org

Creswell, J. W., \& Guetterman, T. C. (2018). Educational Research: Planning, Conducting, and Evaluating Quantitative and Qualitative Research (6th Edition). https://www.researchgate.net/publication/324451568_Educational_Research_Planning_Conducting_and_Eva luating_Quantitative_and_Qualitative_Research_6th_Edition

Crystal, D. (1997). English as a global language Second edition (Second). Cambridge University Press. www.cambridge.org

DeYoung, A. J. (1991). Rural Education: Issues and Practice (Vol. 25). Routledge. https://eric.ed.gov/?id=ED382438

du Plessis, P. (2014). Problems and complexities in rural schools: Challenges of education and social development. Mediterranean Journal of Social Sciences, 5(20), 1109-1117. https://doi.org/10.5901/mjss.2014.v5n20p1109

Febriana, M., Nurkamto, J., Rochsantiningsih, D., \& Muhtia, A. (2018). Teaching in Rural Indonesian Schools: Teachers' Challenges. International Journal of Multicultural and Multireligious Understanding, 5(5), 1-11. https://doi.org/10.18415/ijmmu.v5i5.305

Harmer, J. (2007). How to Teach English (Second). Person Education Limited. https://docs.google.com/viewer?a=v\&pid=sites\&srcid=ZGVmYXVsdGRvbWFpbnxzZXJzZXBvenRmb2xpb 3xneDo1MzRmMTZkMTFINTQ2OWEy

Howley, A., Rhodes, M., \& Beall, J. (2009). Challenges Facing Rural Schools: implications for Gifted Students. Journal for the Education of the Gifted, 32(4), 515-536. http://www.prufrock.com

Jabbarifar, T. (2009). THE IMPORTANCE OF CLASSROOM ASSESSMENT AND EVALUATION IN EDUCATIONAL SYSTEM. Proceedings of the 2nd International Conference of Teaching and Learning, 19.

Knoblauch, D., \& Chase, M. A. (2015). Rural, suburban, and urban schools: The impact of school setting onthe efficacy beliefs and attributions of student teachers. Teaching and Teacher Education, 45, 104e114-114. https://doi.org/10.1016/j.tate.2014.10.001

Looney, A., Cumming, J., van Der Kleij, F., \& Harris, K. (2018). Reconceptualising the role of teachers as assessors: teacher assessment identity. Assessment in Education: Principles, Policy and Practice, 25(5), $442-467$. https://doi.org/10.1080/0969594X.2016.1268090

Mccracken, J. D., David, J., \& Barcinas, T. (1991). High School and Student Characteristics in Rural and Urban Areas of Ohio.

Mente, I., Elliot, D., Hulme, M., Lewin, J., \& Lowden, K. (2011). A Guide to Practitioner Research in Education. SAGE Publications Ltd. https://uk.sagepub.com/en-gb/eur/a-guide-to-practitioner-research-ineducation/book234154

Nunan, D. (1999). Second Language Teaching \& Learning. In Heinle \& Heinle Publishers. Heinle \& Heinle Publishers.

https://books.google.co.id/books/about/Second_Language_Teaching_Learning.html?id=svPtAAAAMAAJ\&r edir_esc $=\mathrm{y}$

Nurfuadah, R. N. (2014, December 11). 10 Masalah Utama Kurikulum 2013 . Https://News.Okezone.Com/. https://news.okezone.com/read/2014/12/11/65/1077829/10-masalah-utama-kurikulum-2013

Ponmozhi, D., \& Thenmozhi, A. (2017). Difficulties Faced By the Rural Students in Learning English at High School Level. IOSR Journal Of Humanities And Social Science (IOSR-JHSS, 22(6), 31-34. https://doi.org/10.9790/0837-2206133134

Ramos Holguín, B., \& Aguirre Morales, J. (2016). English Language Teaching in Rural Areas: A New Challenge for English Language Teachers in Colombia. Cuadernos de Lingüística Hispánica, 27, 219. https://doi.org/10.19053/0121053x.4217

Rich, E., \& Evans, J. (2009). Performative Health in Schools: Welfare Policy, Neoliberalism and Social Regulation. Biopolitics and the "obesity epidemic": Governing bodies. In J. Wright \& V. Harwood (Eds.), Biopolitics and the "obesity epidemic": Governing bodies (Vol. 3, pp. 157-171). Routledge. https://espace.library.uq.edu.au/view/UQ:217929

Sadulloh, U. (2018). PEDAGOGIK ILMU MENDIDIK (Sixth). Alfabeta. https://shopee.co.id/BUKUPEDAGOGIK-ILMU-MENDIDIK-Uyoh-Sadulloh-Alfabeta-i.3046560.1438267967

Uno, H. B., \& Lamatenggo, N. (2010). Teknologi Komunikasi dan Informasi Pembelajaran. Bumi Aksara.

Jurnal Penelitian Pendidikan 